\title{
Healing Brazil's Blue Amazon: The Role of Knowledge Networks in Nurturing Cross-Scale Transformations at the Frontlines of Ocean Sustainability
}

\author{
Leopoldo C. Gerhardinger 1,2,3,4,5*, Philipp Gorris ${ }^{3,5,6}$, Leandra R. Gonçalves 3 3,4,5, \\ Dannieli F. Herbst ${ }^{2,3,5,8}$, Daniele A. Vila-Nova ${ }^{3,5}$, Fabiano G. De Carvalho ${ }^{2,3,5}$, \\ Marion Glaser ${ }^{3,5,9}$, Ruben Zondervan ${ }^{4,5}$ and Bruce C. Glavovic ${ }^{10}$ \\ ${ }^{1}$ Instituto Oceanográfico, Universidade de São Paulo, São Paulo, Brazil, ${ }^{2}$ Department of Biological Sciences, Univille \\ Universidade, Joinville, Brazil, ${ }^{3}$ Ombudsperson of the Sea Network, Brasilia, Brazil, ${ }^{4}$ Earth System Governance Project, \\ Lund, Sweden, ${ }^{5}$ Brazilian Future Ocean Panel, Brasilia, Brazil, ${ }^{6}$ Institute of Environmental Systems Research (IUSF), \\ Osnabrück University, Osnabrück, Germany, ${ }^{7}$ Center of Environmental Studies and Research (NEPAM), University of \\ Campinas (Unicamp), Campinas, Brazil, ${ }^{8}$ Biological Sciences Centre, Ecology and Zoology Department, Federal University of \\ Santa Catarina, Florianópolis, Brazil, ${ }^{9}$ Leibniz Centre for Tropical Marine Research (LG), Bremen, Germany, ${ }^{10}$ School of \\ People, Environment and Planning, Massey University, Turitea, New Zealand
}

OPEN ACCESS

Edited by:

Lyne Morissette,

$M$ - Expertise Marine, Canada

Reviewed by:

Marcus Geoffrey Haward,

University of Tasmania, Australia

Christian T. K.-H. Stadtlander,

Independent Researcher,

United States

*Correspondence:

Leopoldo C. Gerhardinger

leocavaleri@gmail.com

Specialty section:

This article was submitted to

Marine Affairs and Policy,

a section of the journal

Frontiers in Marine Science

Received: 23 August 2017 Accepted: 24 November 2017

Published: 26 January 2018

Citation:

Gerhardinger LC, Gorris $P$,

Gonçalves $L R$, Herbst $D F$,

Vila-Nova DA, De Carvalho FG,

Glaser $M$, Zondervan R and Glavovic BC (2018) Healing Brazil's

Blue Amazon: The Role of Knowledge Networks in Nurturing Cross-Scale Transformations at the Frontlines of

Ocean Sustainability.

Front. Mar. Sci. 4:395.

doi: 10.3389/fmars.2017.00395

\section{HIGHLIGHTS}

- The Anthropocene compels unlocking of ocean-related network capabilities.

- Orchestration of local, regional, and global knowledge networks can augment transformative capacity.

- Transdisciplinary network diagnostics are promising social learning tools.

- Strategic advice for transformational research in ocean territories are provided.

This paper dedicates to understanding of what is needed to achieve the transformation of ocean governance. Based on the theory of transformative agency conceptualized in a multi-level governance context, we build on recent novel inter- and transdisciplinary research in Brazil to explore the opportunities for transformation in the dynamic, complex, and multi-level field of ocean governance. We focus this analysis on three transformation processes toward developing a socially and ecologically coherent marine protected area network as the core of a marine spatial planning process for enhanced ecosystem-based polycentric governance of the country's Exclusive Economic Zone. The findings illuminate leverage points for achieving (much needed) transformation in Brazilian ocean governance and potentially beyond. These include: connecting transformative actions into coherent narratives and testing strategic advice derived from theories of transformative agency to promote regime shifts in ocean governance systems; setting of more ambitious social mobilization targets; fostering orchestration of knowledge-networks considering multiple issues, territorial and institutional levels; implementing institutional learning experiments; supporting transformational trajectories toward co-evolutionary, polycentric, ecosystem- and area-based ocean governance systems; and pursuing gradual, incremental structural understanding of 
a given knowledge network field as a major driver of catalyzing transformative change. Hereby, this article advances understanding of how to better navigate the transformation toward enhanced sustainability in an important part of the Atlantic and hence of our global ocean.

Keywords: knowledge networks, knowledge-exchange, governability, coastal-marine governance, marine protected areas, transformability

\section{INTRODUCTION}

Coastal zones are interfaces between humanity and oceans at the frontline of struggles for global sustainability (Glavovic, 2013a; Glaser and Glaeser, 2014). With a growing human population and changing life styles, the services provided by coastal and marine ecosystems are increasingly important for economic and human well-being (Martínez et al., 2007), as well as heavily impacted by accelerating global change (Hughes et al., 2013; Zondervan et al., 2013; Fernández-Llamazares et al., 2015). These changes act directly and indirectly on societies as they result in increasing degradation of coastal and marine ecosystems strongly affecting human livelihoods and overall well-being through the modification of ecosystem services (Cinner and Bodin, 2010; Cinner, 2011). While this impacts mainly those people living in the coastal zone, all other people on Earth are also affected through the interconnectedness of the oceans with other natural systems, their role in global trade, in marine resources provision, and as a carbon sink (Rockström et al., 2009). Based on past unsustainable trajectories and given the fast on-going changes, innovative transformation toward sustainability in the coastal and marine realms is urgently needed (Rockström et al., 2009; Burke et al., 2011; Rogers and Laffoley, 2011; Glavovic, 2013a,b).

This article explores the emergence of opportunities for transformative change in the dynamic, complex and multi-level field of ocean governance. Combining complementary analytical concepts with quantitative and qualitative methods, our analysis centers on what is needed to transform the governance of the extensive Brazilian Exclusive Economic Zone (Brazilian EEZ, referred to as "Blue Amazon" hereafter), the largest EEZ in South America and one of the largest on the planet-toward more sustainable ocean governance by implementing a socially and ecologically coherent marine protected area network approach as the core of a nation-wide ecosystem-based marine spatial planning process.

In section Materials and Methods-Charting a Blue transdisciplinary transformative Agenda for Ocean Governance in the Anthropocene we outline the conceptual framework of this study. We link the "theory of transformative agency in linked social-ecological systems" by Westley et al. (2013) to the co-evolutionary hierarchical ocean governance approach presented by Jones (2014). Section Transformative Agency to Transdisciplinary Knowledge for Achieving Transformative discusses the role of knowledge for achieving desirable transformative change in a multi-level governance context. Subsequently, we review recent trends in global ocean governance and outline the role of marine protected area networks and marine spatial planning in transforming the current largely fragmented and sector-based approach toward more ecosystem-based means of coastal and marine governance (section Major trends in Ocean Governance: Turning Complex Strategic Mandates into Area-Based Strategies). We then introduce the Brazilian context and outline the research approach for our analysis (section Regional Solution Elements to Face Local to Global Challenges: The Blue Amazon). Section Results and Discussion is a combined results and discussion section. We assess the current ocean governance process in Brazil and explore opportunities for transformation. Section Conclusion: Nurturing Transdisciplinary Capacity to Transform Ocean Governance concludes by highlighting the opportunities and capacities required to achieve desirable transformative change in ocean governance in Brazil, and potentially elsewhere.

\section{MATERIALS AND METHODS-CHARTING A BLUE TRANSDISCIPLINARY TRANSFORMATIVE AGENDA FOR OCEAN GOVERNANCE IN THE ANTHROPOCENE}

\section{Transformative Agency}

Transformation relates to achieving lasting change in the way a system is organized (Folke et al., 2010). Transformative change is needed in how people and institutions interact with coastal natural systems (Gunderson and Holling, 2002; Olsson et al., 2004a; Glaser et al., 2012; Biermann et al., 2016; Patterson et al., 2017). This requires rapid innovation in how coastal and marine areas are currently governed (Young, 2010; Westley et al., 2011, 2013) including new ways of engagement amongst all principal stakeholders; critical and reflexive inquiry into prevailing practices, institutional structures and processes; and enabling incentive structures and drivers. Initiating transformative change also requires collective foresight capabilities for predicting and projecting alternative scenarios for critical transitions.

In this article, we combined conceptual frameworks: (1) Westley et al.'s (2013) framework to understand how and when tranformation in complex systems can be achieved, (which is based on) (2) Holling's (1986) “adaptive cycle," and (3) Dorado's (2005, p. 113) conceptualization of "opportunity contexts" in relation to institutional entrepreneurship to move toward a theory of transformative agency (Figure 1). More specifically, Holling's adaptive cycle encompasses four phases (i) exploitation, (ii) conservation, (iii) release, and (iv) reorganization in an infinite loop. This suggests that options for transformation differ by phase. To explore the "quality of the opportunity" to achieve transformative change, we build on Dorado (2005) who analyses the ability of social movements to use "opaque," "transparent," 


\section{Brazilian Ocean Governance Systems}

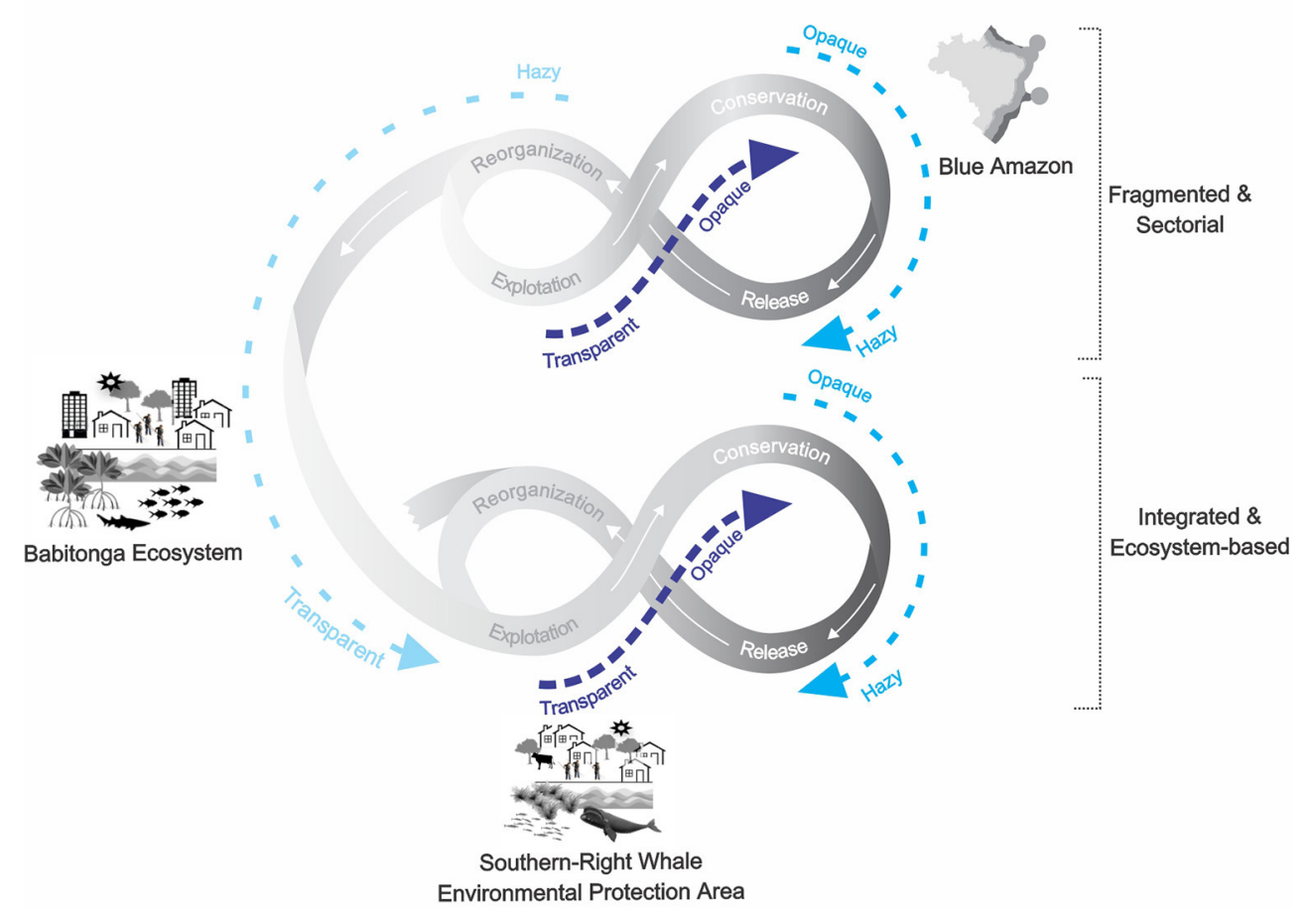

FIGURE 1 | Model of agency, context and problem domain innovation, and the shift to a new configuration of the Brazilian Ocean Governance system (adapted from Westley et al., 2013).

or "hazy" openings in the political system. In order to achieve a desirable transformation, Westley et al. (2013) propose strategies for the three characteristic system phases:

(1) transparent to opaque context: the ground for change should be prepared, and a systemic exploration and building of novel ideas undertaken;

(2) opaque to hazy context: while the system opens for change, resources should be released to experiment with innovative ideas;

(3) hazy to transparent context: as the system starts to reorganize, the stimulation of emerging innovations and partnerships is needed.

The above conceptual framework sheds light on the opportunity context for governance-led transformation in coastal and marine social-ecological systems. Based on assessing the phase-specific opportunity context, strategies that may augment transformative capacity can then be distilled.

\section{Co-evolutionary Polycentric Hierarchical Ocean Governance}

The realization of a complex and transformative ocean governance agenda requires experimentation with different modes of governance at various levels of implementation (Kooiman and Bavinck, 2013). From self-governance or bottomup (community-led and science-guided) to hierarchical or top-down approaches (governmental-led and science-based)different modes of ocean governance at multiple system levels can combine the dynamics of authoritative, constraining, disciplining and stabilizing features on the one hand; and generative, enabling, empowering, and innovative countervailing features, on the other (Glavovic, 2013a).

A compelling approach to accelerate transformation in multi-level ocean governance is the idea of co-evolutionary hierarchical governance (Jones, 2014; Chen and Ganapin, 2015). The principal idea is that ocean governance needs to be nested and simultaneously occur at multiple levels in the organizational hierarchy to reflect the fact that coastal and marine ecosystems are spatially interconnected so that issues need to be addressed at different geographical scales. In this approach, centralized agencies set the strategic objectives and standards for operation in collaboration with societal actors-while spatially distributed and territorially bounded (place-based) quasi-autonomous centers of decision-making units nested across administrative levels experiment with the organization of the related incentives to support sustainability-enhancing governance processes. The state keeps an indirect regulatory role in this model, working through persuasion, partnerships, markets, communities, associations and other means while retaining a degree of hierarchical control to ensure that strategic social, environmental, and economic objectives are achieved through negotiated compliance. This approach may nurture participation and institutional learning in synergy with negotiation and compliance. Best practice examples 
and lessons learnt may hereby be transferred across space and time and between levels in administrative hierarchies.

This concept by Jones (2014) offers potential for balancing bottom-up with top-down approaches in an interconnected polycentric governance system. Moreover, it acknowledges that the previously outlined "opportunity contexts" may differ between levels in the organizational hierarchy, between places, and between phases in the coevolution of social-ecological system contexts; and that transformations commonly involve multilevel and multi-phase processes that engage diverse actors in the system they seek to transform (Westley et al., 2013).

\section{Transdisciplinary Knowledge for Achieving Transformative Agency}

Social-ecological outcomes arise in the context of regionally specific and interconnected ethical, cultural, political, social, economic, institutional, technological, and behavioral processes. Aggregating pertinent knowledge on complex interrelated coastal and marine social-ecological systems is thus key for engaging with and developing appropriate ocean governance systems (Fanning et al., 2007; Glaser and Glaeser, 2014). Inclusive policies at multiple levels that account for grassroots actors and processes (Leach et al., 2012; Chuenpagdee et al., 2013; Future Earth, 2013; ICSF, 2016) and include culturally and economically diverse groups in multi-level knowledge-building efforts are needed to generate the appropriate knowledge base for ocean governance (Berkes, 2009). This knowledge base then needs to be mobilized and institutionalized at multiple scales to combat unsustainable practices, and to incentivise practices that yield sustainable coastal and ocean outcomes.

Facilitating the flow of information and knowledge from multiple sources, its synergistic build-up and augmentation at decision-making interfaces are crucial for successful ocean governance (Olsson et al., 2004b; Janssen et al., 2006). In our increasingly interconnected world, linkages between geographically separate ocean governance actors from various sectors (e.g., fishers, resource users and managers, tourism operators, scientists and other actors) can create shared knowledge that enhances research and communication capacities, and mobilizes decision-makers to address problems at multiple governance levels (Clark, 1998, p. 1; Creech and Willard, 2001; Cornell et al., 2013; Jones, 2014). Linkages need to develop both horizontally, between actors and institutions at the same system level, and vertically across system levels and scales, for creating knowledge networks that capacitate governance actors with access to wide-ranging sources of information and knowledge in ways that improve learning and coordination (Young et al., 2007; Newig et al., 2010). Collaborative research and learning processes are thus being increasingly sought to identify and treat complex (or "wicked") problems and the root causes of collective choices that foster (un)sustainable outcomes and (mal)adaptive practices (e.g., Jentoft and Chuenpagdee, 2009; Hermans et al., 2011; Angelstam et al., 2013; Fox et al., 2013; Davies et al., 2015).

Yet gaps in formal and informal collaborative structures to integrate efforts can limit coordination capacities and create obstacles to achieving sustainability goals (Gorris et al., 2015). To address this, the co-design, and co-production of knowledge across organizational and territorial levels is of high priority for global sustainability science, e.g., in the global research platform Future Earth (and related initiatives such as Future Earth Coasts, IMBeR and Oceans Knowledge-Action Network) and other international ocean-related sustainability knowledge networks (Fazey et al., 2012; Cornell et al., 2013; van der Hel, 2016). How this can be achieved in order to facilitate transformative change remains a key question in sustainability research.

\section{Major Trends in Ocean Governance: Turning Complex Strategic Mandates into Area-Based Strategies}

As the world's oceans have entered the core agenda for international science and policy-making, it is increasingly acknowledged that the current governance of coastal and marine ecosystems faces severe shortcomings. Consensus now is that ocean governance in the Anthropocene (e.g., Zondervan et al., 2013) - a new era in which natural systems are extensively affected by human agency (Biermann, 2014; Steffen et al., 2015), poses three principal challenges: the interconnectedness of marine systems; the rising pressures on common resources; and the need for enhanced global coordination in governance. These challenges are to be addressed by social innovators, for instance in the implementation of Sustainable Development Goals (SDGs) with the adoption of ocean sustainability as one of the 17 SDGs (Visbeck et al., 2014; ICSU, ISSC, 2015); in the preparations for the negotiation of a new implementing agreement on biodiversity in Areas Beyond National Jurisdiction (high-seas) under the United Nations Convention Law of the Sea; in the completion of the first World Ocean Assessment (2016www.worldoceanassessment.org); in the Sendai Framework for Disaster Risk Reduction 2015-2030; and in the Paris Climate Agreement within the UN Framework Convention on Climate Change (2016). These processes (amongst others, see review by Campbell et al., 2016) have led to increased interest, and renewed global ocean related efforts in a variety of policy fields.

Area-based strategies in particular have been attributed a key role for strengthening ecosystem-based approaches as a promising means to address the continuing problems in the coastal and marine realm (World Bank, 2006). This is where marine protected areas (MPAs) come to the fore as one important institutional solution for sustainable marine area-based management and conservation (Jones, 2014). MPAs pursue a wide array of objectives and are implemented on different spatial and institutional levels ranging from small-scale community, to multi-million hectare national parks (Laffoley, 2008). The term "Marine Protected Area" covers a range of interventions for area-based marine management including spatially and temporally sustainable resource management (Pomeroy et al., 2007; Dudley, 2008; Laffoley, 2008). MPAs and, on a broader territorial scale, MPA networks are the heart of ecosystem-based approaches to ocean governance and are well suited to address most problems affecting ocean health (see IUCN World Commission on Protected Areas, 2008; Lowry et al., 
2009, p. 287; Convention on Biological Diversity ${ }^{1}$, Programme of work on Protected Areas, COP 7 Decision VII/28; Alexander and Armitage, 2014). Moreover, ideally MPAs and MPA networks are to be promoted as "policy experiments" (Fox et al., 2012a,b).

The design and implementation of MPA networks largely rely on a critical ecosystem-based, sustainability-enhancing process, namely Marine Spatial Planning (MSP): a “...public process of analyzing and allocating the spatial and temporal distribution of human activities in marine areas to achieve ecological, economic and social objectives that have been specified through a political process" (http://msp.ioc-unesco.org/). MSPs involve collaborative and social learning processes that are expected to leverage societal transformation to address ocean issues at higher spatial levels (Ehler and Douvere, 2009; Olsen et al., 2014). Yet, MSP is still in nascent stages in most countries worldwide and the conflicts and equity issues its implementation entails are at the center of global sustainability challenges requiring multi-directional, purposive, deliberate and socially just negotiation processes (Berkhout, 2002; Chapin et al., 2009; O’Brien, 2011; Merrie and Olsson, 2014).

\section{Regional Solution Elements to Face Local to Global Challenges: The Blue Amazon}

In this section, we explore the opportunity contexts for transformative action in the governance of the extensive Brazilian Exclusive Economic Zone (EEZ) toward implementing a socially and ecologically coherent marine protected area network approach as the core of a nation-wide ecosystem-based marine spatial planning process. Brazil has more than 9,000 km of coastline with 17 coastal states and 463 coastal cities that shelter about a quarter of the country's 204 million population (Marroni and Asmus, 2013). The national territory encompasses an Exclusive Economic Zone of about 3.5 million $\mathrm{km}^{2}$ and a continental shelf of 912 thousand $\mathrm{km}^{2}$. This enormous ocean territory has been declared the "Blue Amazon" (4.4 million $\mathrm{km}^{2}$ ) by the Brazilian Intergovernmental Council for Marine Affairs (the country' highest national ocean governance forum) to "...call attention to a marine area, larger than the green [forest counterpart], that is unimaginably rich" (see www.mar.mil.br/ secirm/ingles/promar.html) (Figure 2). The grand challenge of governing such an enormous ocean area is to develop successful governance processes that are embedded in the Brazilian context integrated with local and global knowledge and undertaken in coproduction with stakeholders and decision-makers in line with planetary needs and boundaries (Rockström et al., 2009) and international policies such as the SDGs.

The Blue Amazon is part of a global multi-level governance system (see Figure 3). We used part of this governance system to assess interrelated opportunities for transformation from international (Figure 3-level A), national (e.g., Figure 1Brazilian EEZ level) and subnational levels (Figure 3-level C1 is a designated intermunicipal Environmental Protection Area-Southernright Whale EPA and; C2 is the step-zero of a

\footnotetext{
${ }^{1}$ Convention on Biological Diversity (1992). Programme of work on Protected Areas, COP 7 Decision VII/28 United Nations. Available online at: https://www. cbd.int/decision/cop/?id=7765
}

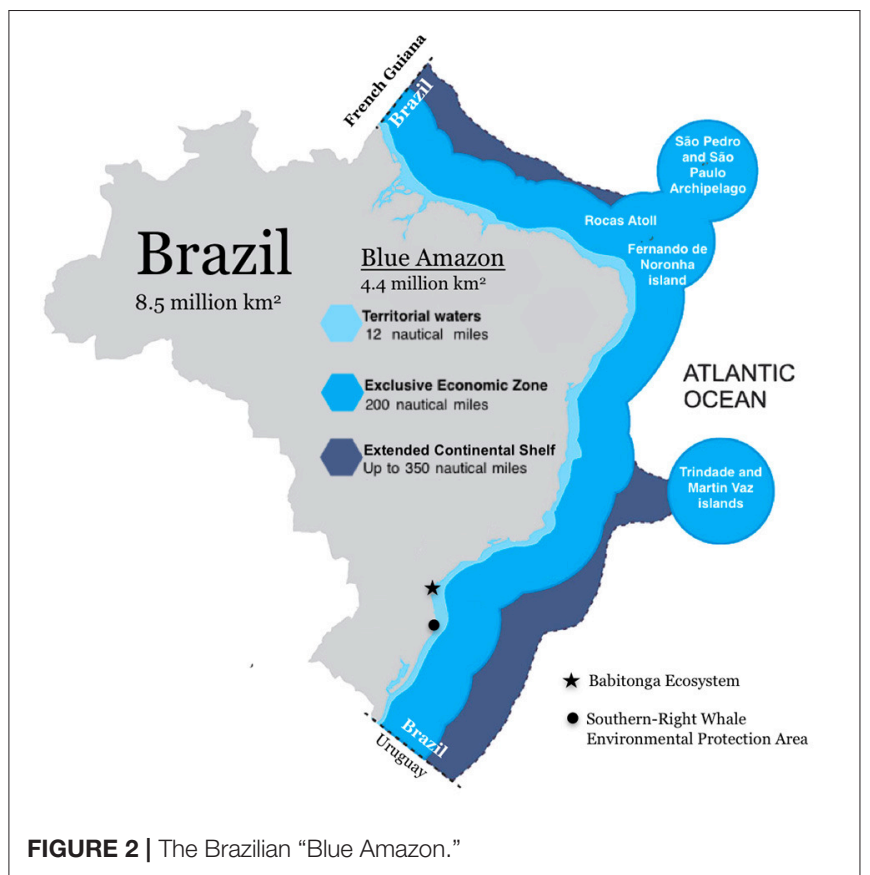

novel ocean governance system at Babitonga bay surrounding ecosystem).

The assessment is based on reviewing empirical research on Brazilian ocean governance, gray literature and current discourses, as well as direct participation in the implementation of several knowledge-networks and organization of stakeholder workshops resulting in collaborative policy papers. We also draw on more recent quantitative social network analysis and qualitative results of co-designed social network experiments (co-led by LCG, LRG, DFH, FGC, DAVN, and others) under the auspices of an emerging Ombudsperson of the Sea network (OS) in 2012 (Ouvidoria do Mar, 2012; Gerhardinger et al., 2014a) and 2016 (ICSF, 2016; Ouvidoria do Mar, 2016). In 2016, the OS launched the first national campaign of an intended regular "self-diagnostics" process to engage in experimental learning with all Brazilian coastal and marine non-governmental networks identified in previous assessments (Gerhardinger et al., 2015a). A focus on fisheries (ICSF, 2016) and on coastal and marine management issues governed through MPAs approaches emerged (Ouvidoria do Mar, 2013). Active members of these organizations were identified and invited by OS volunteers to engage in a collaborative civil society social network analysis (hence the emphasis on the prefix "self-" in this collective experiment). This set out to explore with which other networks they had connected to, communicated with or developed any joint actions since the first gathering of the network members. The collectively produced structurally explicit network map explores the degree of centrality of each organization or knowledge-network involved in the diagnostic process. Our analysis enables an assessment of how to better connect the existing knowledge networks relevant for coastal and marine governance currently operating in Brazil. 


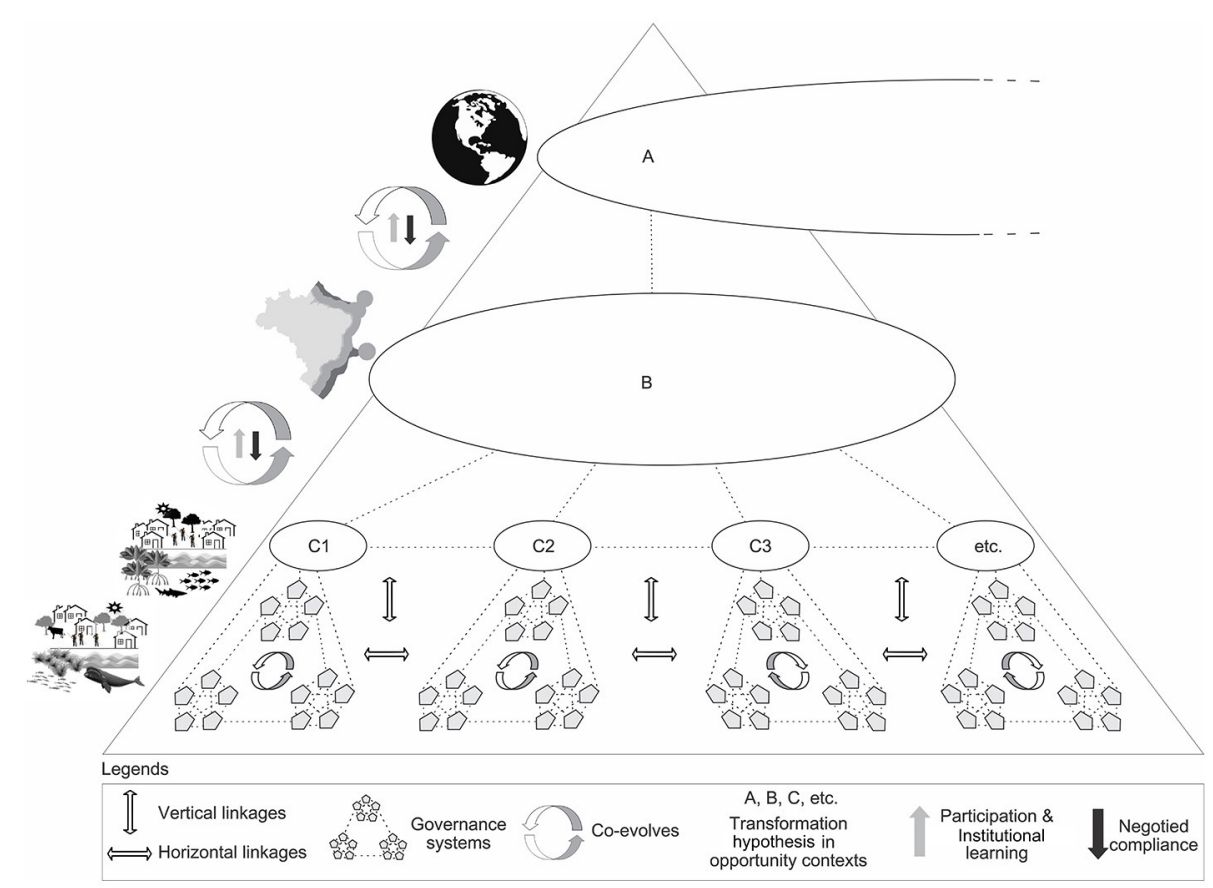

FIGURE 3 | A framework to conceptualize how transformation can be achieved in a polycentric co-evolutionary hierarchical governance context in Brazil (adapted from Jones, 2014).

\section{RESULTS AND DISCUSSION}

\section{Brazilian Ocean Governance: The Problem-Domain}

Bernard et al. (2014) illustrate that Brazil has undergone a serious shift toward downgrading, downsizing, degazetting, and reclassifying many protected areas over the past 10 years. The largely unstable institutional and political condition in the emergent economy of Brazil currently further complicates ocean governance (Polette and Vieira, 2009; Wever et al., 2012; Pinheiro et al., 2015; Fearnside, 2016).

The expert-based recommendations of the Ajaccio Declaration $^{2}$ (as were outlined in Marseille of 2013) highlight that a global MPA coverage of $<3 \%$ of global oceans is still insufficient for maintaining ecosystems services. This problem also exists in Brazil (Klein et al., 2015). Few of its 65 MPAs were designated in the past few years despite international and national policy commitments Brazil has recently signed, and their current coverage accounts for around $3.14 \%$ of Brazil's coastal and marine zone, with only $1.57 \%$ of marine areas under special governance regimes in federal jurisdiction (Ministério do Meio Ambiente, 2010, 2013; Gerhardinger et al., 2011).

Moreover, the Ministry of Environment set the ecological spatial prioritization criteria for national-level marine

\footnotetext{
${ }^{2}$ Ajaccio Declaration (2013). Appendix 1: Recommendations of the $3 \mathrm{rd}$ International Marine and Protected Areas Congress (Marseille - France, 21-27 of October, 2013). Available online at: http://www.impac3.org/images/pdf/Ajaccio/ ajaccio_appendix1_en.pdf
}

conservation planning in 2002 (updated in 2007) to enable large-scale, strategic ocean planning). These have been largely ignored by other ministerial agencies. The current, largely unstable institutional and political state of affairs in Brazil continuously challenges the design and implementation of a coherent national ocean governance vision (Gerhardinger et al., 2015a; Pinheiro et al., 2015; Fearnside, 2016), particularly one that integrates MPAs and MSP with other integrated coastal zone management and sustainable territorial development policies and instruments (Vivacqua et al., 2009; Marroni and Asmus, 2013). Among recent Brazilian executive and legislative actions dealing with MPAs and MSP at the Blue Amazon level, the emerging National Institute for Oceanographic Research (Instituto Nacional de Pesquisas Oceanográficas e Hidroviárias) and the 2013 submission of a proposal to the Brazilian National Congress of an entirely new Marine Bill are crucial steps toward more sustainable ocean governance which, however, still lack political momentum at the national level.

Brazilian ocean planning at the EEZ level still largely occurs in a fragmented and sectorial manner (Wever et al., 2012; De Freitas et al., 2014). Unfortunately, in Brazil, MSP is often seen as an environmental conservation tool rather than as a way to implement ecosystem-based management by finding space for both biodiversity conservation and sustainable socioeconomic development (De Freitas et al., 2015). Our experience also shows that the matter is debated either only between conservationists that hold positive views, or in more open fora, where industrial and business stakeholders are usually skeptical about MSP implementation. 
A robust MSP agenda requires a new legal framework and provisions for effective administrative routines (Gonçalves and Hirota, 2014), including the integration of large sectors (and related governmental policies and actors) such as energy, mining and transport (e.g., oil and gas, port infrastructure development and others) with fisheries and marine conservation goals (e.g., marine reserves or no-take zones).

The choice to create a MPA is more likely to be a political choice than a scientific or technical knowledge based decision, or even a social demand (Chuenpagdee et al., 2013). In this regard, Brazil looks back at a history of conflicts in previous overly topdown MPA designation or MSP planning processes that now hamper political support for new designations (Diegues, 2008; De Freitas et al., 2015).

Gerhardinger (2014) describe an emerging perception amongst decision-makers of the need for structural changes in governance approaches to achieve co-design (including major stakeholders), in the development and implementation of management plans. MPA management plans are usually expensive and normative, focus on lengthy diagnostic descriptions of the natural and social systems, and allow for little opportunities for ecosystem users to influence the process (Gerhardinger, 2014). Beyond MPA policies, some (if not all) of these implementation malaises are also present in other public policies in coastal zones, e.g., integrated coastal management and hydrological resource policies (Polette and Vieira, 2009; Marroni and Asmus, 2013). This may even relate to Brazilian democratic culture, a major learning phase still under way in a country that has, during the past 15-20 years, merely started to consolidate more decentralized societal steering structures.

Despite the near enough omnipresent consensus in environmental governance literature that higher social participation is indispensable (Armitage et al., 2009; Glaser et al., 2010; Wever et al., 2012; Ferrol-Schulte et al., 2013; Jones, 2014), most Brazilian MPAs and associated governing instruments (e.g., management plans or councils) are still not co-designed with local social constituencies (Diegues, 2008; Gerhardinger et al., 2011, 2014a; Ouvidoria do Mar, 2012, 2013, 2016; Oliveira Júnior et al., 2016). Sustaining long-term collaboration in coastal and ocean governance thus is a wicked problem in Brazil, where institutional and resource provision is highly unstable; and where the political culture of social participation in MPAs still rarely fuels vibrant public environmental stewardship over the longer term (Marroni and Asmus, 2013; Trimble et al., 2014; De Freitas et al., 2015; Gerhardinger et al., 2015b; Serafini et al., 2017), with few exceptions (Glaser et al., 2005). Nevertheless, higher levels of active participation remain paramount for engaging local ecological knowledge in Brazilian MPA planning. Consultative or deliberative management councils are mandatory by law in every Brazilian MPA, and the principal means of enabling public participation. Management councils may be regarded as regional social learning platforms with a pivotal role as knowledge-exchange fora among multiple societal actors with different interests and conflicts (Gerhardinger et al., 2009).

The evolution of polycentric coastal and marine governance in Brazil will require adaptations in how management councils are collaboratively formed and steered, and how management plans are co-designed and implemented, in ways that are locally relevant and in line with international goals like the SDGs.

\section{Building Narratives for Transformations on the Ocean Governance Horizon}

Starting from the international level, a strategic convergence with national knowledge networks' priorities on MPAs and MPA networks finds its way through Brazilian-state commitments to the Aichi 11 target of the Convention on Biological Diversity and the SDG agenda (Table 1). Following the implementation phase in the global evolution of national and subnational MSPs (Merrie and Olsson, 2014), a policy discourse calling for a national MSP agenda has recently emerged in Brazil. At least two high-level workshops (in 2011 and in 2014) were organized with the participation of government authorities, academia and non-governmental organizations to discuss ways forward (De Freitas et al., 2014). In May 2016, the Brazilian Secretariat of the Interministerial Commission for the Sea Resources (SECIRM) approved an 18-month workplan on MSP that will initiate a governmental learning agenda to navigate the stepzero of a National MSP. Moreover, Brazil presented 6 Voluntary Commitments to the UN Ocean Conference (held in June of 2017), and at least four are directly related to strengthening areabased governance approaches in the country. How collaborative these new processes and emerging arena will be is still a matter of debate and high expectations by civil society organizations.

At a national level, the opportunity context is still largely "opaque," but slowly turning into "hazy" and starting to release resources for innovation (Table 2). While the overall Brazilian ocean governance system is still largely stable in a low responsiveness, centralized, fragmented/sectorial planning approach-small pockets of resources and on-going support for novelty in the national problem domain exist.

While major flaws in the Brazilian MPA network are widespread (Gerhardinger et al., 2011), one does find local success stories, across several of Brazil's 463 coastal cities, 17 coastal states and dozens of long-standing and experienced multi-sectorial councils (Gerhardinger et al., 2015b). These offer insights for neighboring territories where governance actors may be stuck with a particular problem, or social actors are only starting to mobilize into new step-zero processes.

For instance, the Baleia Franca [Sourthernright-whale] Environmental Protection Area (BF-EPA), Santa Catarina state, Brazil is one of several environmental governance systems across Brazil that are testing novel approaches (Menezes et al., 2014; Chiaravalloti et al., 2015; Gerhardinger et al., 2015b; Tofoli et al., 2015). A gradual increase in coastal-marine governability followed the designation of this regional-level coastal-marine governing system throughout its initial 13-year implementation trajectory was described by Gerhardinger (in press). In 2012, the Federal government of Brazil officially designated this protected area as a pilot-project for novel public management tools, namely the elaboration of a "Strategic" Management Plan. Key-individuals acted as important buffers, lessening or moderating the impact of the national-level institutional and 
TABLE 1 | An illustrative sample of multi-level, synergistic, or mutually supporting strategic intentions toward area-based ocean governance systems reforms in Brazil.

\begin{tabular}{|c|c|}
\hline Strategic guidance & Description \\
\hline \multicolumn{2}{|l|}{ INTERNATIONAL } \\
\hline The Future We Want & $\begin{array}{l}\text { The Rio+20 United Nations Conference on Sustainable Development refers to the critical goal reaffirmed the targets of the Conference of } \\
\text { the Parties to the Convention on Biological Diversity, that by 2020, } 10 \text { percent of coastal and marine are to be conserved through } \\
\text { area-based conservation measures [Aichi 11] (United Nations, 2012; paragraph 177; p. 31). }\end{array}$ \\
\hline Ajaccio Declaration & $\begin{array}{l}\text { The Ajaccio Declaration (Marseille, October, 2013) acknowledges a long road remains ahead as MPA coverage is still }<3 \% \text { of global } \\
\text { oceans, and further sets out general and specific priorities and recommendations to mainstream the global MPA agenda. }\end{array}$ \\
\hline Rio+20 parallel events & $\begin{array}{l}\text { Several parallel events called for an expansion of the number and quality of MPAs, e.g., recommendations of the Rio Dialogues on } \\
\text { Oceans; the Programmatic Agenda of the Ouvidoria do Mar (2012) and; a petition of Brazilian marine conservation NGOs calls for the } \\
\text { designation of new MPAs (De Freitas et al., 2015). }\end{array}$ \\
\hline Brazilian official state goals & $\begin{array}{l}\text { A } 10 \text { per cent target was officially acknowledged in Brazil with Resolution CONABIO N } 06 / 2013 \text {; a } 4 \% \text { target was later stated at the } \\
\text { national IX th Sectoral Plan for Ocean Resources (2016-2019) and; Brazilian government submitted a Voluntary Commitment to the UN } \\
\text { Ocean Conference (\#OceanAction19669) to fund the implementation of 5-10\% area-based conservation measures until } 2027 \text {. }\end{array}$ \\
\hline
\end{tabular}

Examples of bottom-up, top-down and collaborative modes of governance are given to depict the range of approaches to be acknowledged in a polycentric view.

political disturbances (Gerhardinger et al., 2009, 2011, 2015b; Macedo et al., 2013; Gerhardinger, 2014). Key individuals were also responsible for the attraction of actors sharing similar frames for action on interactive learning and collaboration. They were crucial for structuring the governing system, enabling windows of opportunity for institutional innovation, and in navigating transformative periods. This shows that at subnational level, we find transitions at different phases. For instance, the current Baleia Franca EPA opportunity context seems to be better depicted as moving from "transparent to opaque," as it is currently "institutionalizing innovations" in the attempt to resolve old dilemmas in MPA planning by testing and hopefully establishing new groundwork for the co-design of strategic management plans in the country (Table 2).

Now follows a case of horizontal, inter-scalar diffusion of innovation. The lessons from 16 years of MPA structuration at BF-EPA are informing actors engaged with another neighboring ecosystem, the Babitonga bay coastal and estuarine system, located in the state of Santa Catarina. A public environmental governance coursework is being co-developed by local leaders of both initiatives, to allow for mutually enriching capacitation through field visits and knowledge exchange activities.

The Babitonga Bay is the southernmost large mangrove ecosystem in the subtropical Atlantic (Brazil) (Cremer et al., 2006). It is surrounded by six coastal cities with one million coastal citizens in the largest metropolitan region of Santa Catarina state. Babitonga has been listed in eight Federal Decrees by the Ministry of Environment attributing national ecological relevance to this region. This coastal-marine area is also intensively used by over 1,700 fishers, has two large active ports and about another seven currently pursuing environmental licensing, posing great challenges for more integrative governance approaches. Mining, aquaculture and tourism are also present so that social conflicts and ecological degradation have ensued (Cremer et al., 2006). Since 2005, attempts to designate an MPA by the Federal Government have been frustrated, largely because of an overly top-down approach.

In 2010, a company was fined for spilling 116.5 thousand liters of oil in the bay, and the money is currently being applied by the Public Ministry and Federal Court of Justice to improve the environmental governance of the region. Since early 2015, these state organizations are in partnership with the regional University of Joinville (Univille) and the Sea Memories Collective to facilitate the co-design of a new governance system for the Babitonga ecosystem (www.babitongaativa.com). This is done through an ecosystems-based project that combines transdisciplinary marine social-ecological systems science, an ambitious level of social participation and clear policy goals.

In its first 24 months, the project has been regularly engaged with about 400 direct resource users in several interrelated activities, including dozens of MSP workshops, and a 10month transdisciplinary course on ecosystem stewardship ("ecocidadania" in Portuguese) to build core-groups of concerned citizens in each of the six cities (including community leaders and school teachers). These activities aimed to engage people with current and novel coastal and marine policies and decision-making platforms. The project Babitonga Ativa thus coordinates various governmental and societal organizations in the co-design of new governance structures, as part of a bottom-up and inclusive regional MSP process, which is likely to include a MPA. The Bay's most critical ecosystem services are being spatially located and valued to guide the negotiation of trade-offs in collective planning and zoning. The project was invited by the Federal government licensing authority to help merge several environmental monitoring programs for the ports of the Bay into one coherent ecosystems-based monitoring proposal. 


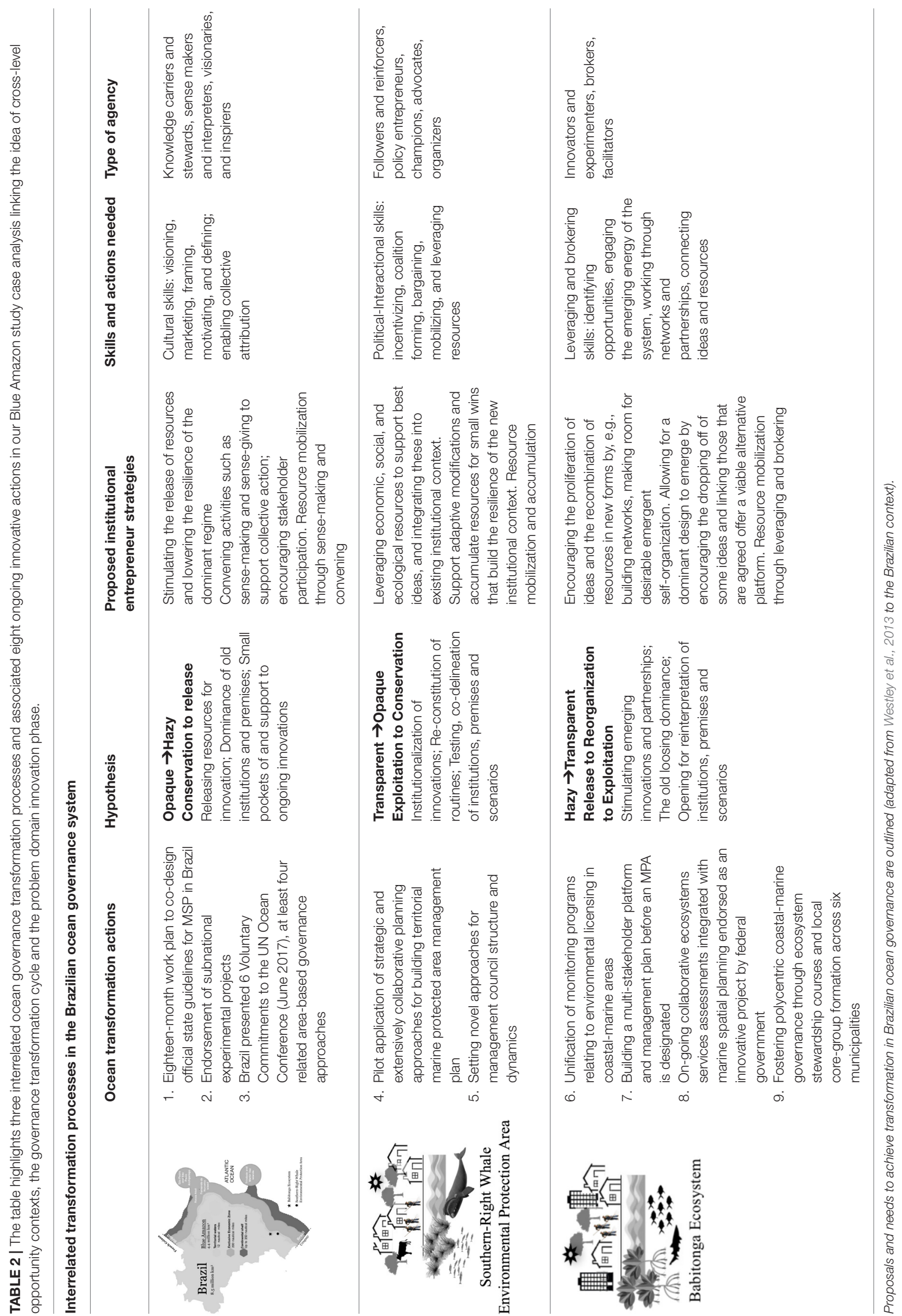


In future years, this may also lead to the first marine protected area ever formally designated in Brazil with an operating management council and a management plan already in place. The management council election was held in May 2017 and now a group of 28 private, public and civil society institutions will be launching the co-design of novel instruments for coastal-marine governance, including a financial mechanism to safeguard the long-term sustainability of this transformational enterprise.

The above illustrates the potentials of diffusing innovation processes through regional networks in the step-zero phase of MPA social-ecological trajectories. In Babitonga Bay a university and a transdisciplinary network are pivotal drivers in the co-evolution of polycentric governance; Gorris et al. (2015) show that there are other options. The innovative, and hopefully transformative, nature of the Babitonga initiative has been endorsed by several organizations that are working to learn from and support this subnational process. The SECIRM, PainelMar, and the Future Earth Coasts project (www. futureearthcoasts.org) are looking at the Babitonga project as an institutional-learning experiment examining several crosslevel learning hypotheses (e.g., by testing several ecosystemsbased instruments) as depicted in Figure 1. Moreover, the horizontal relationship among governance actors of Babitonga and BF EPA opens avenues toward win-win partnerships for inter-regional learning and experimentation. Such a regional diffusion process between MPA governance systems mediated by regional networks is an important means to facilitate learning for increased transformative agency.

The endorsement of the Babitonga ecosystem as a demonstration case-study makes local change agents part of a "stimulating emerging innovations and partnerships" transition phase (Table 2). This is characterized by a "hazy to transparent" opportunity context, where old ways of governing lose their dominance, and institutions and beliefs are opening to reinterpretation in a novel multi-stakeholder platform which enables the exchange of ideas, evaluation of scenarios and definition of new ecosystem-based governance trajectories.

\section{Leveraging Transformation in Brazilian Ocean Governance at Multiple Levels: The Role of Knowledge-Networks}

This section illuminates the actual and potential role of Brazilian ocean knowledge-networks in supporting transformation across places and administrative levels. A range of ocean related knowledge networks with governmental and non-governmental actors has emerged in Brazil over the past decade. Our quantitative assessment of knowledge networks interacting in relation to Brazil's Blue Amazon yielded 64 national nongovernmental, 15 governmental and 10 international knowledge networks. Table 3 shows the profile of a selected sample of the ocean knowledge networks operating in Brazil. Some of these networks can operate as "networks of networks" to foster crossnetwork coordination of knowledge-exchange (Gerhardinger and Borgonha, 2012; Gerhardinger et al., 2014b,a, 2015a; Muller et al., 2014). The OS network, TeiaPesca and PainelMar (see Table 3) are good examples of this, their constituents (members of civil society, governmental organizations and private funding agencies) currently claim to pursue the stronger integration of policy-relevant knowledge in the Brazilian ocean-related domain of expertise (see Figure 2). As so many networks at multiple levels in this "chaotic space" these "networks of networks" have "orchestration" capacities (sensu Abbott and Bernstein, 2015). Orchestrators are organizations with limited authority and modest resources that work through other institutions by utilizing soft and indirect means of influence. They provide ideational (e.g., cognitive and normative) and material support (e.g., resources, technologies, etc.) to a selected set of institutions for setting and pursuing common agendas.

In order to integrate relevant knowledge and effectively diffuse innovation for fostering governance transformation, orchestration of the broad knowledge network landscape is needed. In 2016, an important step to increase understanding of the Brazilian marine governance actor landscape was the first OS self-diagnostics process. This campaign engaged 40 volunteers from the 64 Brazilian networks, to co-produce a report (Ouvidoria do Mar, 2016) entitled "Potentializing interactions amongst coastal and marine networks for transformations toward sustainability." Figure 3 displays the network structure of actors concerned with or affected by particular complex problems at different organizational, jurisdictional, and geographic scales.

For instance, Figure 2 shows the Ombudsperson of the Sea's (OM in the center of the network) central position in the network and hence its distinct potential as an orchestrator. The Brazilian Network of Law of the Sea Lawyers (RAdvDM on Figure 3), in turn, is an emerging network led by law experts from the Federal University of Brasilia. Despite their valuable capacity to offer other knowledge-networks legal support on emerging ocean governance issues, they are still in a peripheral position in the broader network field. Several other similar conclusions can be drawn from the analysis. These are taken into account OM volunteers in their self-capacitating efforts.

A self-diagnostic analysis at the network level thus represents a social experiment that reflects the myriad of civil society needs relating to Brazil's ocean governance. Hereby, it contributes to find practical ways to link and empower governance actors to pursue transformative agendas. This type of diagnostic approach offers strong potential to render integrative assessments (e.g., Borja et al., 2016) of marine systems health and related dimensions of ocean and coastal sustainability more collaborative, transdisciplinary and inclusive.

Reforming governing systems poses knowledge-related problems that span across ocean knowledge networks. Especially challenging objectives, such as the call to implement area-based ocean governance structures for covering $4-10 \%$ of the Brazilian Blue Amazon in upcoming years (Magris et al., 2013), or 30\% globally (O'Leary et al., 2016) by 2030, show the need for synergistic cooperation amongst ocean knowledge networks. In view of these challenges, a socially and ecologically sensitive and coordinated response is needed to improve ocean-related sustainability goals through a more rapid designation and implementation of new MPAs and MSP, assuming that central scientific, political and transparent societal engagement criteria are respected. To achieve this, network orchestrators can bring 
TABLE 3 | Profile of some important ocean knowledge-action networks operating in the Brazilian problem-domain.

\begin{tabular}{|c|c|c|}
\hline Network & Level & Profile \\
\hline Future Earth Coasts & International & $\begin{array}{l}\text { Future Earth Coasts is an international cross-disciplinary research collaboration providing the knowledge and } \\
\text { support to accelerate transformations to a sustainable planet in the coastal zone. }\end{array}$ \\
\hline $\begin{array}{l}\text { Transformar: } \\
\text { Transdisciplinary network in } \\
\text { adaptive co-management } \\
\text { for ecodevelopment }\end{array}$ & National & $\begin{array}{l}\text { Academically based self-governed interdisciplinary research-action network encompassing five universities in } \\
\text { the south and southeast regions of Brazil, working through adaptive co-management in support of } \\
\text { sustainable territorial development processes. }\end{array}$ \\
\hline $\begin{array}{l}\text { TeiaPesca } \\
\text { Brazilian Artisanal Fisheries } \\
\text { Web }\end{array}$ & National & $\begin{array}{l}\text { Mixed scientists/fishers network aiming to improve communication and articulation amongst those dedicated } \\
\text { to artisanal fisheries in Brazil to enable creative solutions to small-scale fisheries problems and opportunities } \\
\text { (Gerhardinger et al., 2014b). }\end{array}$ \\
\hline Sea Memories Collective & Subnational & $\begin{array}{l}\text { A multi-institutional and self-governed network that enables transdisciplinary initiatives integrating scientific } \\
\text { and artistic activities related to biodiversity, culture and conservation along the Brazilian coastline } \\
\text { (Gerhardinger and Borgonha, 2012). }\end{array}$ \\
\hline $\begin{array}{l}\text { PainelMar } \\
\text { Brazilian Future Ocean } \\
\text { Panel }\end{array}$ & National-International & $\begin{array}{l}\text { PainelMar is a Brazilian-based, multi-stakeholder organization that is structuring itself to orchestrate (sensu } \\
\text { Abbott and Bernstein, 2015) ocean knowledge networks to enhance national policy foresight capabilities } \\
\text { (Muller et al., 2014; Gerhardinger et al., 2015a). }\end{array}$ \\
\hline Ombudsperson of the Sea & National & $\begin{array}{l}\text { Initiated at the People's Summit of Rio+20-a self-governed event gathering more than } 70 \\
\text { research-action coastal-marine institutions in Latin America and elsewhere to think of, and co-design } \\
\text { integrated, cross-network strategies for improved governability of the Brazilian ocean territory. }\end{array}$ \\
\hline
\end{tabular}

higher-level governance processes into greater convergence with the desires of, for instance, small-scale fishers' and other potential ecosystem stewards to set-up new or foster already established marine protection norms and vice-versa.

The Ombudsperson of the Sea "network of networks" agenda can be potentially exemplary in this regard, given its explicit call for reforms in the MPA governance architecture and support to their implementation (Ombudsperson of the Sea, 2013). While this network attempts to foster cross-level linkages and societal political influence across the country, it still faces challenges such as the limited digital inclusion of some ecosystem users (e.g., small-scale fishers), and other capacities required attention as illustrated in the self-diagnostic report.

While the dynamics of horizontal or less hierarchical networks will play a critical role in influencing governance transformation in Brazil, the potentials and limitations of this approach in other countries may differ in terms of the permeability/openness of the state to public participation and influence. While the OS volunteers have not yet jointly enrolled directly in the implementation of specific area-based projectspast interactions have focused in the national-level-their new strategic plan points in this direction. Therefore, the OS has a large role to play in enabling a creative and broad, knowledgeexchange environment to empower its constituent individual members to improve their innovation processes on the ground; as well as critical support and articulation of policy priorities in a country that so urgently needs political will and leadership to use the outlined transformative opportunities. For instance, the OS is playing an important role in enabling cross-network information flow around processes of building policy briefs and advocacy statements (over a hundred of such were issued by ocean networks since 2012).

The number and diversity of actors presently engaging in ocean governance have never been so promising in Brazil. Scaling-up collaboration amongst different actors can improve the shared capacities to govern the ocean. While we argue that knowledge networks should aim to improve ocean governance capacities in a country facing serious turbulences in the democratic state of affairs, knowledge networks alone-no matter how integrative-will not resolve these underlying governability issues and dramas. At the very least, there is a compelling need for networked knowledge-to-action initiatives-to make explicit the need to translate "ocean sustainability" understanding into practical action and change in specific areas, places or territories.

Our analysis points to the need for incentives to achieve distributed but interrelated processes of marine scaping (Figure 4). Marine scaping (Toonen and Tatenhove, 2013) is a framework for assessing informational processes related to integrated marine governance by staging and ordering marine activities in time and space while accounting for the interplay between seascape, humanscape and mindscape. Thus, co-design of area-based and polycentric governance solutions must not only consider notions of property, territory or metrics of extent, but also ecological effectiveness, biodiversity, representation, connectivity and ecosystem services targets should be achieved through equitable processes with equitable outcomes (Koehn et al., 2013; Larson et al., 2013; Blomley, 2015; Spalding et al., 2016).

Networks can also be regarded as "communities of practice"because constituents share an interest in something that they do, and interact regularly to learn how to do it better; and/or "epistemic communities"-because they share knowledge about the causation of social or physical phenomena and a common set of normative beliefs about what will benefit human welfare in their area of competence (Haas, 1992; Wenger and Snyder, 2000; Dedeurwaerdere, 2005). As such, they continue to aggregate, articulate and disseminate knowledge relevant for decision makers (Haas, 1992) in the Brazilian ocean governance problem-domain. Orchestrators in the Brazilian ocean governance system thus function as important knowledge 


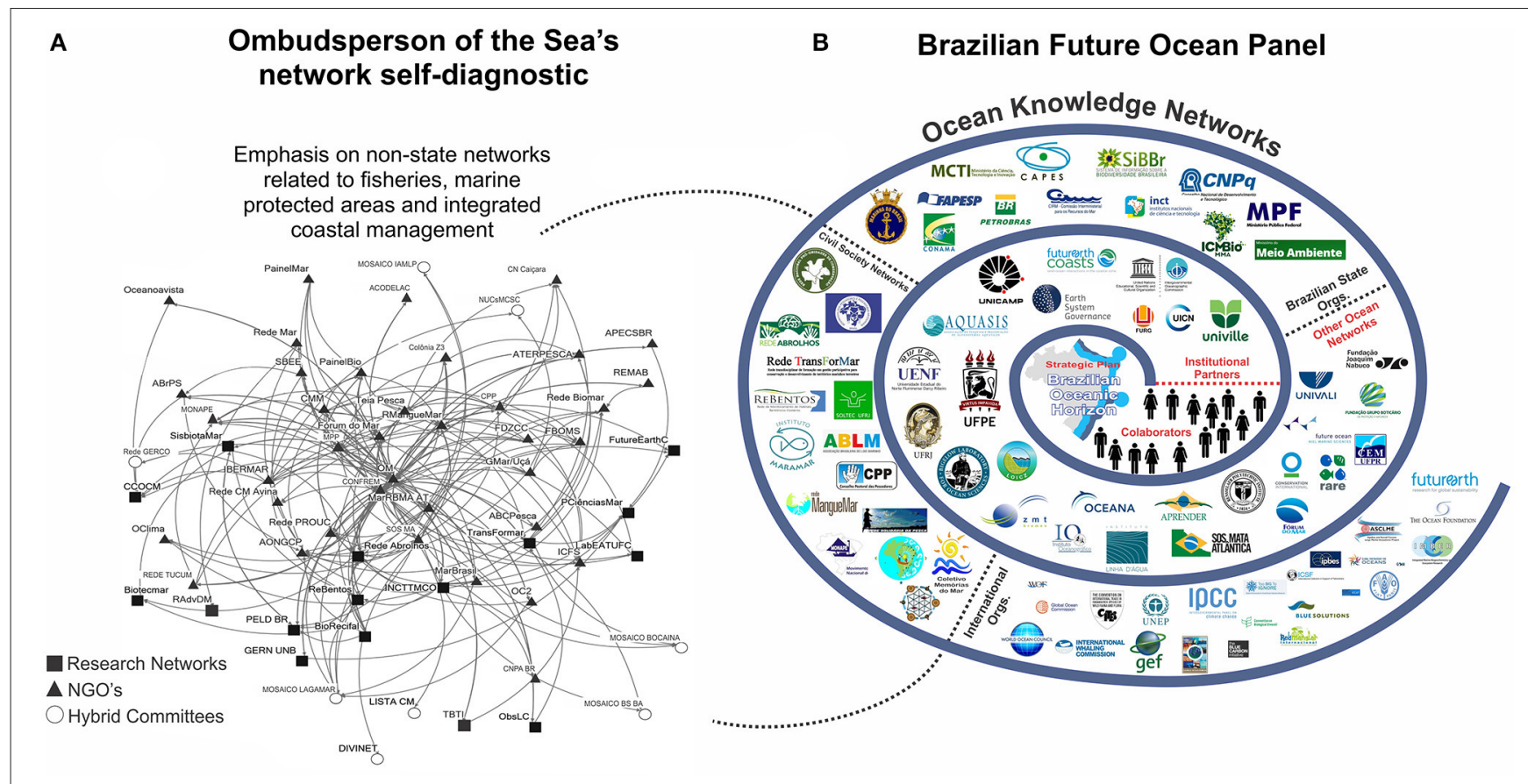

FIGURE 4 | Depiction of the centrality of institutional actors (mostly non-state networks) in the structure of Brazilian ocean problem-domain (A) (Ombudsperson of the Sea self-diagnostic process) and; the structuration of one coastal-marine orchestrator (B), the Brazilian Future Ocean Panel (PainelMar).

holders assuming a central role in identifying favorable opportunities contexts at multiple levels and help relevant stakeholders to make use of windows of opportunity for achieving transformation in ocean governance when they open.

\section{CONCLUSION: NURTURING TRANSDISCIPLINARY CAPACITY TO TRANSFORM OCEAN GOVERNANCE}

This article identifies ongoing incremental transformation actions in the larger national ocean governance system. But the Great Acceleration, a hallmark of the Anthropocene, demands radical and rapidly implemented innovations in ocean governance systems. While innovations may progress with different speed and in varying ways, transformation will require a concerted wave of interlinked cross-scale and cross-level changes, which encompass diverse modes of governance.

In order for innovation processes to surface and endure in todays' Brazilian political turmoil, they will also need to rely on the agency of key individuals as buffers against institutional instabilities. In connection with this, we argue for a "healing agency" that enables the unlocking of personal and institutional capacities available in opportunity contexts. At network/institutional levels, orchestrators will need to play a key role in unlocking the potential knowledge capacities of networks more assertively in order to pave the way toward transformation with appropriate material, ideational, cognitive and normative support.
This paper outlines the challenges and opportunities for the coevolution of a socially and ecologically sensitive ocean knowledge network approach as the core of an ecosystem-based marine spatial planning process for Brazil's EEZ. We applied multiple methods to critically expose a significant part of the knowledge-network field of a whole country's ocean problemdomain. We also highlighted nine on-going transformative actions that, if mutually nurturing and interconnected, may tip the operating Brazilian ocean governance regime toward transforming into an alternative state to better support the sustainability of coastal and marine social-ecological systems.

Decades of ocean governance in Brazil have created valuable experience and knowledge across networks. Although marine governance agents hold enormous contextually grounded capacities-they are often disconnected from each other hindering timely exchange of relevant data, knowledge and solutions.

Below, we distill our findings to six key ingredients of an integrated transformational strategy that, in our opinion, will accelerate the transformation of the governance system in Brazil toward a polycentric hierarchical and coevolutionary ocean governance system, which is more integrated, informed and responsive to ocean governance challenges.

We suggest that the effectiveness and value of transdisciplinary diagnostics and prognostics tools be systematically assessed to (1) connect transformative actions into coherent narratives and test strategic advice derived from theories of transformative agency to promote changes in state in social-ecological systems (Table 2). Scientists must help actors develop very clear storylines that policymakers can 
deal with. To tap the rich knowledge available in Brazil, social networks are needed that actively link ocean governance actors across sectors, issues, regions, disciplines and interest groups to facilitate the coevolution of polycentric ocean governance systems. Our analysis highlights the important potential role of orchestrators, whose structural and functional position may boost cross-fertilization amongst knowledge-networks and reduce transaction costs for transformative agency of marine governance actors across Brazil and beyond.

Synergizing cross-level transformational work at the Blue Amazon level will require projects and initiatives with ever more (2) ambitious social mobilization targets. Higher legitimacy in reforming the allocation of, and access to ocean areas may only significantly improve through incentives for extensive and sustained social mobilization to exchange knowledge and formulate stewardship agendas.

The large size and interrelated geographies and associated plural and multiple jurisdictions on oceans and related lands, also require social innovators to (3) foster orchestration of knowledge-networks considering multiple issues, territorial and institutional levels. Brazil has 463 coastal cities that are arguably managing the coast in a very fragmented fashion. Approaches that advance co-evolutionary polycentric multi-level governance need to co-develop consistent work plans for vertically and horizontally integrating policies from local to planetary scales.

The crafting of synergistic actionable knowledge requires interacting ocean governance agents who learn individually from their experience, but also engage in the co-design and coproduction of knowledge through (4) consciously planned policy experiments. Our analysis illuminates that ocean governance challenges are to be met with governance actors' capacity and willingness for experimenting with solutions treated as clearly defined working hypotheses. The setting of social experiments through action research methodologies and the embedding of regular evaluation as a normal component of transdisciplinary ventures offers promising avenues to capacitate knowledgenetworks for ocean governance transformations. The OS's selfdiagnostic process and the interlinkages between our eight transformative actions (Table 2) illustrate the potential of piloting transformations in ocean governance.

Changes are also needed in how the Brazilian ocean is governed through knowledge-building platforms and their associated planning instruments (e.g., MPA management council and plans). Incentives for augmented influence of eco-centric worldviews on ocean policymaking are also paramount to reconnect our governing and social systems to the biosphere, acknowledging humans as integral part of the social-ecological complex that is the essence of nature in the Anthropocene. An ocean governance transformational process should accommodate the integration of sectorial planning approaches to enable subnational (5) transformational trajectories toward co-evolutionary, polycentric, ecosystemand area-based ocean governance systems. Current innovatory actions are to be acknowledged as part of "transformations in the making."

We argue that comprehensively (6) pursuing gradual, incremental structural understanding of a given knowledge network field as a major driver of catalyzing transformative change is important for increasing the capacities of knowledge networks and orchestrators. Information about the qualities, structure and patterns of interaction among networks and engagement with knowledge brokers and other key-individuals will contribute to a more sensitive and thus assertive provisioning of normative and cognitive support to match the diversity of political ecologies with the coevolution of polycentric hierarchical governance systems. Moreover, this may help network orchestrators in synergizing on-going management councils and related working groups, thematic chambers, and thus build novel, more permeable and flexible cross-scale relational and institutional architectures for knowledge-to-action operations.

Co-designed social learning activities, such as the selfdiagnostics approach, offer promising pathways to integrate these ingredients with metaphoric, descriptive or structurally explicit network analysis methods. We suggest that the development of this transdisciplinary methodology can improve the toolkit for area-based ocean governance; help guide future policy interactions by fostering ecosystem stewardship and; hopefully accelerate transformations toward sustainable human-nature relations in the marine realm.

Finally, while making a case for the relevance of the proposed transformation strategy ingredients, they are neither meant as an exhaustive list, nor as theoretical or methodological "do's" and "don't's." Rather, while this paper emphasizes the role of transdisciplinary approaches, we remain strongly supportive of interdisciplinary scholarship, particularly of ongoing efforts to inductively develop diagnostic frameworks and tools with empirical case-study research. To support comprehensive transformation a broad range of individual, organizational/network and system level capabilities, skills and infrastructure will also be needed to increase the modeling capacity of humans for projecting future scenarios-including more open methods that enable artistic/aesthetic expressions as well as sophisticated software applications including big data analytics, visualizations, agent-based modeling and artificial intelligence, amongst others. These fields of knowledge coproduction should therefore also be noted and explored by aspiring orchestrators.

\section{AUTHOR CONTRIBUTIONS}

LCG, PG, LRG, DFH, FGC, and DAVN: designed and conducted research; LCG, PG, LRG, DFH, DAVN, FGC, MG, RZ, and BCG performed data analysis and wrote the paper.

\section{ACKNOWLEDGMENTS}

This paper is the fruit of many interactions between researchers, and between researchers and practitioners. If we left anyone out, take it to be said, please. We thank the volunteers of all Brazilian knowledge networks taking part in the self-diagnostics process, in particular Viviane Amaral and Rafael Ummus from the Ombudsperson of the Sea for co-leading the self-diagnostics 
process leading to Figure 4A. We are indebted to Instituto Linha D'Água and Fundo Socioambiental Casa-Caixa, the International Collective in Support of Fish Workers, and the International Foundation for Agriculture Development, for co-funding several events from which this paper derives. LCG acknowledges the support provided by CAPES Ciências do Mar for funding TransForMar Network (process 23038.051622/2009e11) and the

\section{REFERENCES}

Abbott, K. W., and Bernstein, S. (2015). The high-level political forum on sustainable development: orchestration by default and design. Glob. Pol. 6, 222-233. doi: 10.1111/1758-5899.12199

Alexander, S. M., and Armitage, D. (2014). A social relational network perspective for MPA science. Cons. Lett. 8, 1-13. doi: 10.1111/conl.12090

Angelstam, P., Elbakidze, M., Axelsson, R., Dixelius, M., and Törnblom, J. (2013). Knowledge production and learning for sustainable landscapes: seven steps using social-ecological systems as laboratories. AMBIO 42, 116-128. doi: $10.1007 / \mathrm{s} 13280-012-0367-1$

Armitage, D., Plummer, R., Berkes, F., Arthur, R. I., Charles, A. T., Davidson-Hunt, I. J., et al. (2009). Adaptive co-management for social-ecological complexity. Front. Ecol. Environ. 7, 95-102. doi: 10.1890/070089

Berkes, F. (2009). Evolution of co-management: role of knowledge generation, bridging organizations and social learning. J. Environ. Man. 90, 1692-1702. doi: 10.1016/j.jenvman.2008.12.001

Berkhout, F. (2002). Technological regimes, path dependency and the environment. Global Environ. Change 12, 1-4. doi: 10.1016/S0959-3780(01)00025-5

Bernard, E., Penna, L. A. O., and Araújo, E. (2014). Downgrading, downsizing, degazettement, and reclassification of protected areas in Brazil. Cons. Biol. 28, 939-950. doi: 10.1111/cobi.12298

Biermann, F. (2014). The Anthropocene: a governance perspective. Anth. Rev. 1, 57-61. doi: 10.1177/2053019613516289

Biermann, F., Bai, X., Bondre, N., Broadgate, W., Arthur Chen, C. T., Dube, O. P., et al. (2016). Down to Earth: contextualizing the anthropocene. Glob. Environ. Change 39, 341-350. doi: 10.1016/j.gloenvcha.2015. 11.004

Blomley, N. (2015). The territory of property. Prog. Hum. Geogr. 40, 593-609. doi: $10.1177 / 0309132515596380$

Borja, Á., Elliott, M., Andersen, J. H., Berg, T., Carstensen, J., Halpern, B. S., et al. (2016). Overview of integrative assessment of marine systems: the ecosystem approach in practice. Front. Mar. Sci. 3:20. doi: 10.3389/fmars.2016.00020

Burke, L., Reytar, K., Spalding, M., and Perry, A. (2011). Reefs at Risk Revisited. Washington, DC: World Resource Institute (WRI).

Campbell, L. M., Gray, N. J., Fairbanks, L., Silver, J. J., Gruby, R. L., Dubik, B. A., et al. (2016). Global oceans governance: new and emerging issues. Annu. Rev. Environ. Resour. 41, 102014-021121. doi: 10.1146/annurev-environ-102014-021121

Chapin, F. S. I., Kofinas, G. P., and Folke, C. (2009). Principles of Ecosystem Stewardship. Resilience-Based Natural Resource Management in a Changing World. New York, NY: Springer.

Chen, S., and Ganapin, D. (2015). Polycentric coastal and ocean management in the Caribbean Sea Large Marine Ecosystem: harnessing communitybased actions to implement regional frameworks. Environ. Dev. 17, 264-276. doi: 10.1016/j.envdev.2015.07.010

Chiaravalloti, R. M., Delelis, C., Tofoli, C., Padua, C. V., Ribeiro, K. T., and Menezes, G. A. (2015). Federal protected areas management strategies in Brazil: sustainable financing, staffing, and local development. Nat. Conserv. 13, 30-34. doi: 10.1016/j.ncon.2015.05.003

Chuenpagdee, R., Pascual-Fernández, J. J., Szeliánszky, E., Luis Alegret, J., Fraga, J., and Jentoft, S. (2013). Marine protected areas: re-thinking their inception. Mar. Pol. 39, 234-240. doi: 10.1016/j.marpol.2012.10.016

Cinner, J. E. (2011). Social-ecological traps in reef fisheries. Glob. Environ. Change. 21, 835-839. doi: 10.1016/j.gloenvcha.2011.04.012
São Paulo Research Foundation for a post-doc scholarship (FAPESP process no2016/26158-8) and; PG acknowledges financial support from the Alexander-von-Humboldt (AvH) professorship for Environmental Economics of the Osnabrück University (UOS). BCG acknowledges the support of Future Earth Coasts and Massey University and the Earthquake Commission of New Zealand.

Cinner, J. E., and Bodin, O. (2010). Livelihood diversification in tropical coastal communities: a network-based approach to analyzing "livelihood landscapes". PLoS ONE 5:11999. doi: 10.1371/journal.pone.0011999

Clark, H. C. (1998). Formal Knowledge Networks: A Study of Canadian Experience. Winnipeg: international Institute for Sustainable Development (IISDA). Available online at: http://www.iisd.org/pdf/fkn.pdf

Cornell, S., Berkhout, F., Tuinstra, W., Tàbara, J. D., Jäger, J., Chabay, I., et al. (2013). Opening up knowledge systems for better responses to global environmental change. Environ. Sci. Pol. 28, 60-70. doi: 10.1016/j.envsci.2012.11.008

Creech, H., and Willard, T. (2001). Strategic Intentions: Managing Formal Knowledge Networks for Sustainable Development. Winnipeg: IISD. Available online at: http://www.iisd.org/pdf/2001/networks_strategic_intentions.pdf

Cremer, M. J., Oliveira, T. M. N., and Morales, P. R. D. (2006). Diagnóstico Ambiental da Baía da Babitonga. Joinville: Editora da UNIVILLE.

Davies, K. K., Fisher, K. T., Dickson, M. E., Thrush, S. F., and Heron, R. Le. (2015). Improving ecosystem service frameworks to address wicked problems. Ecol. Soc. 20:37. doi: 10.5751/ES-07581-200237

Dedeurwaerdere, T. (2005). The Contribution of Network Governance to Sustainable Development. Université catholique de Louvain, Institute for Sustainable Development and International Relations, Paper no. 13. Available online at: http://www.iddri.org/Evenements/Seminaires-reguliers/s13_ dedeurwaerdere.pdf

De Freitas, D. M., Xavier, L. Y., and Shinoda, D. (2014). Jornada de Gerenciamento Costeiro e Planejamento Espacial Marinho. Instituto Oceanográfico da Universidade de São Paulo, Cidade Universitária, São Paulo (SP) - Brasil.

De Freitas, R. R., Gerhardinger, L., Chamy, P., and Seixas, C. S. (2015). "Governança dos oceanos na Rio+20: O debate sobre Áreas Marinhas Protegidas na perspectiva da gestão compartilhada," in Governança Ambiental no Brasil: Entre o Socioambientalismo e a Economia Verde, 1st Edn., eds F. Castro, C. T. Futemma (Jundiaí: Paco), 137-168.

Diegues, A. (2008). Marine Protected Areas and Artisanal Fisheries in Brazil. SAMUDRA Monograph 54. Chennai: International Collective in Support of Fishworkers.

Dorado, S. (2005). Institutional entrepreneurship, partaking, and convening Organ. Stud. 26, 385-414. doi: 10.1177/0170840605050873

Dudley, N. (2008). Guidelines for Applying Protected Area Management Categories. Gland: International Union for Conservation of Nature (IUCN). doi: 10.2305/IUCN.CH.2008.PAPS.2.en

Ehler, C., and Douvere, F. (2009). Marine Spatial Planning: A Step-byStep Approach Toward Ecosystem-Based Management. Intergovernmental Oceanographic Commission and Man and the Biosphere Programme. IOC Manual and Guides No. 53, ICAM Dossier No. 6. Paris: UNESCO.

Fanning, L., Mahon, R., McConney, P., Angulo, J., Burrows, F., Chakalall, B., et al. (2007). A large marine ecosystem governance framework. Mar. Pol. 31, 434-443. doi: 10.1016/j.marpol.2007.01.003

Fazey, I., Evely, A. C., Reed, M. S., Stringer, L. C., Kruijsen, J., White, P. C. L., et al. (2012). Knowledge exchange: a review and research agenda for environmental management. Environ. Conserv. 40, 1-18. doi: 10.1017/S037689291 200029X

Fearnside, P. M. (2016). Brazilian politics threaten environmental policies. Science (80) 353, 746-748. doi: 10.1126/science.aag0254

Fernández-Llamazares, A., Díaz-Reviriego, I., Luz, A. C., Cabeza, M., Pyhälä, A., and Reyes-García,. V. (2015). Rapid ecosystem change challenges the adaptive capacity of local environmental knowledge. Glob. Environ. Change 31, 272-284. doi: 10.1016/j.gloenvcha.2015.02.001 
Ferrol-Schulte, D., Wolff, M., Ferse, S. C. A., and Glaser, M. (2013). Sustainable Livelihoods Approach in tropical coastal and marine social-ecological systems: a review. Mar. Pol. 42, 253-258. doi: 10.1016/j.marpol.2013.03.007

Folke, C., Carpenter, S. R., Walker, B., Scheffer, M., Chapin, T., and Rockström, J. (2010). Resilience thinking: integrating resilience, adaptability and transformability. Ecol. Soc. 15:20. doi: 10.5751/ES-03610-150420

Fox, E., Poncelet, E., Connor, D., Vasques, J., Ugoretz, J., McCreary, S., et al. (2013). Adapting stakeholder processes to region-specific challenges in marine protected area network planning. Ocean Coast. Manage. 74, 24-33. doi: 10.1016/j.ocecoaman.2012.07.008

Fox, H. E., Mascia, M. B., Basurto, X., Costa, A., Glew, L., Heinemann, D., et al. (2012a). Reexamining the science of marine protected areas: linking knowledge to action. Conserv. Lett. 5, 1-10. doi: 10.1111/j.1755-263X.2011.00207.x

Fox, H., Soltanoff, C., Mascia, M., Haisfield, M., Lombana, A. V., Pyke, C. R., et al. (2012b). Explaining global patterns and trends in marine protected area (MPA) development. Mar. Pol. 36, 1131-1138. doi: 10.1016/j.marpol.2012.02.007

Future Earth (2013). Future Earth Initial Design. Paris: Future Earth Research for Global Sustainability.

Gerhardinger, L. C. (2014). Agency of Key People in Governability and Innovations at Baleia Franca [Southern-Right Whales] Environmental Protection Area, Brazil. Ph.D. thesis in Environment and Society, Núcleo de Estudos e Pesquisas Ambientais Campinas State University (São Paulo state, Brazil).

Gerhardinger, L. C. (in press). "Cultivando a governabilidade regional costeira e marinha: os sete passos da Área de Proteção Ambiental da Baleia Franca (Santa Catarina, Brazil)," in Governança Adaptativa Para O Desenvolvimento de Territórios Sustentáveis, eds C. S. Seixas, P. F. Freire, R. Medeiros, and P. Quevedo (São Carlos: RIMa Editora).

Gerhardinger, L. C., Andrade, J., Aziz, J., Gandini, F., Gonzaga, N., Lianza, S., et al. (2014b). "Building a national network in support of artisanal fisheries in Brazil," in Presented at the 2nd World Small-Scale Fisheries Congress (Merida).

Gerhardinger, L. C., and Borgonha, M. (2012). "Transdisciplinary ventures in tackling wicked coastal-marine governance problems: the case of the 'Programa Memórias do Mar' in Brazil," in Presented at the Planet Under Pressure Conference-New Knowledge Towards Solutions (London).

Gerhardinger, L. C., de Castro, F., and Seixas, C. S. (2015b). "Scaling-up small-scale fisheries governability through Marine Protected Areas in Southern Brazil," in Governing the Governance of Small-Scale Fisheries, eds S. Jentoft and R. Chuenpagdee (Amsterdam: Springer Verlag), 339-357.

Gerhardinger, L. C., Godoy, E. A. S., and Jones, P. J. S. (2009). Local ecological knowledge and the management of marine protected areas in Brazil. Ocean Coast. Manage 52, 154-165. doi: 10.1016/j.ocecoaman.2008.12.007

Gerhardinger, L. C., Godoy, E. A. S., Jones, P. J. S., Sales, G., and Ferreira, B. P. (2011). Marine protected dramas: the flaws of the brazilian national system of marine protected areas. Environ. Manage. 47, 630-643. doi: $10.1007 / \mathrm{s} 00267-010-9554-7$

Gerhardinger, L. C., Gonçalves, L., Motta, F. S., Schneider, S., Carvalho, F. G., and Vila-Nova, D. (2014a). "Setting and implementing a programmatic agenda for coastal-marine networks in Brazil," in Enhancing Stewardship in Small-Scale Fisheries: Practices and Perspectives, eds P. McConney, R. P. Medeiros, and M. Pena. CERMES Technical Report No. 73 Special Edition.

Gerhardinger, L. C., Gonçalves, L. R., and Vila-Nova, D. (2015a). "Orchestrating solution-oriented agendas to emerging ocean challenges in Brazil", in Conference Paper. March 2015. Conference: Ocean Sustainability Science (Kiel).

Glaser, M., and Glaeser, B. (2014). Towards a framework for cross-scale and multilevel analysis of coastal and marine social-ecological systems dynamics. Reg. Environ. Change 14, 2039-2052. doi: 10.1007/s10113-014-0637-5

Glaser, M., Cabral, N., and Ribeiro, A. L. (2005). Gente, ambiente e pesquisa: manejo transdisciplinar no manguezal RESEX (NUMA/UFPA). Belem: Universidade Federal do Para/Núcleo de Meio Ambiente.

Glaser, M., Radjawali, I., Ferse, S., and Glaeser, B. (2010). Nested participation in hierarchical societies? Lessons for social-ecological research and management. Intern. J. Sust. Societ. 2, 390-414. doi: 10.1504/IJSSS.2010. 035571

Glaser, M., Ratter, B. M. W., Krause, G., and Welp, M. (2012). "New approaches to the analysis of human-nature relations," in Human-Nature Interactions in the Anthropocene: Potentials of Social-Ecological Systems Analysis, eds M. Glaser, G. Krause, B. M. W. Ratter, and M. Welp (New York, NY; Abington: Routledge). 3-12.
Glavovic, B. (2013a). Coastal innovation paradox. Sustainability 5, 912-933. doi: $10.3390 /$ su5030912

Glavovic, B. (2013b). Coastal Innovation Imperative. Sustainability 5, 934-954. doi: $10.3390 /$ su 5030934

Gonçalves, L. R., and Hirota, M. (2014). "The collective construction of a law of the sea in Brazil. 2014," in Abstract Presented at IMBER - Integrated Marine Biogeochemistry Open Conference (Bergen).

Gorris, P., Glaser, M., Gerhardinger, L. C., and Ferreira, B. P. (2015). "Exploring strengths and weaknesses of regional marine protected area governance using a network approach: a case study from north-eastern Brazil," in Entangled? Linking Governance Systems for Regional-Scale Coral Reef Management: Analysis of Case Studies in Brazil and Indonesia, ed P. Gorris (Bremen). Available online at: https://opus.jacobs-university.de/frontdoor/index/index/ docId/211

Gunderson, L., and Holling, C. S. (2002). Panarchy: Understanding Transformations in Human and Natural Systems. Washington, DC: Island Press.

Haas, P. M. (1992). Introduction: epistemic communities and international-policy coordination-introduction. Int. Organiz. 46, 1-35. doi: $10.1017 / \mathrm{S} 0020818300001442$

Hermans, F., Haarmann, W., and Dagevos, J. (2011). Evaluation of stakeholder participation in monitoring regional sustainable development. Region. Environ. Change 11, 805-815. doi: 10.1007/s10113-011-0216-y

Holling, C. S. (1986). "The resilience of terrestrial ecosystems: local surprise and global change," in Sustainable Development of the Biosphere, eds W. C. Clark and R. E. Munn (Cambridge: Cambridge University Press), 292-317.

Hughes, T. P., Huang, H. U. I., and Young, M. A. L. (2013). The wicked problem of China's disappearing coral reefs. Conserv. Biol. 27, 261-269. doi: 10.1111/j.1523-1739.2012.01957.x

ICSF (2016). Vital Fisheries: Setting Pathways for the Implementation of International Guidelines for Small-Scale Fisheries in Brazil. Available online at: https://sites.google.com/site/ssfguidelines/brazil

ICSU, ISSC (2015). Review of the Sustainable Development Goals: The Science Perspective. Paris: International Council for Science (ICSU).

IUCN World Commission on Protected Areas (2008). Establishing Resilient Marine Protected Area Networks - Making It Happen. Washington, DC: IUCN World Commission on Protected Areas, National Oceanic and Atmospheric Administration, and the Nature Conservancy.

Janssen, M. A., Bodin, Ö., Anderies, J. M., Elmqvist, T., Ernstson, H., McAllister, R. R. J., et al. (2006). Toward a network perspective of the study of resilience in social-ecological systems. Ecol. Soc. 11:15. doi: 10.5751/ES-01462110115

Jentoft, S., and Chuenpagdee, R. (2009). Fisheries and coastal governance as a wicked problem. Mar. Pol. 33, 553-560. doi: 10.1016/j.marpol.2008. 12.002

Jones, P. J. S. (2014). Governing Marine Protected Areas: Resilience through Diversity. New York, NY: Oxon.

Klein, C. J., Brown, C. J., Halpern, B. S., Segan, D. B., McGowan, J., Beger, M., et al. (2015). Shortfalls in the global protected area network at representing marine biodiversity. Scien. Rep. 5:17539. doi: 10.1038/srep17539

Koehn, J. Z., Reineman, D. R., and Kittinger, J. N. (2013). Progress and promise in spatial human dimensions research for ecosystem-based ocean planning. Mar. Policy 42, 31-38. doi: 10.1016/j.marpol.2013.01.015

Kooiman, J., and Bavinck, M. (2013). "Theorizing governability-the interactive governance perspective," in Governability of Fisheries and Aquaculture. MARE Publication Series, Vol. 7, eds M. Bavinck, R. Chuenpagdee, S. Jentoft, and J. Kooiman (Dordrecht: Springer), 9-30. doi: 10.1007/978-94-007-6107-0_2

Laffoley, D. A. (2008). Towards Networks of Marine Protected Areas. The MPA Plan of Action for IUCN's World Commission on Protected Areas. Gland: IUCN-WCPA.

Larson, S., De Freitas, D. M., and Hicks, C. C. (2013). Sense of place as a determinant of people's attitudes towards the environment : implications for natural resources management and planning in the Great Barrier Reef. Aus. J. Environ. Manage. 117, 226-234. doi: 10.1016/j.jenvman.2012.11.035

Leach, M., Rockström, J., Raskin, P., Scoones, I., Stirling,. A. C., Smith, A., et al. (2012). Transforming Innovation for Sustainability. Ecol. Soc. 17:11. doi: 10.5751/ES-04933-170211 
Lowry, G. K., White, A. T., and Christie, P. (2009). Scaling up to networks of marine protected areas in the philippines: biophysical, legal, institutional, and social considerations. Coast. Manage. 37, 274-290. doi: 10.1080/08920750902851146

Macedo, H. S., Vivacqua, M., Rodrigues, H. C. L., and Gerhardinger, L. C. (2013). Governing wide coastal-marine protected territories: a governance analysis of the Baleia Franca Environmental Protection Area in South Brazil. Mar. Pol. 41, 118-125. doi: 10.1016/j.marpol.2013. 01.008

Magris, R. A., Mills, M., Fuentes, M. M. P. B., and Pressey, R. L. (2013). Analysis of progress towards a comprehensive system of marine protected areas in Brazil. Nat. Conserv. 11, 81-87. doi: 10.4322/natcon.2013.013

Marroni, E. V., and Asmus, M. L. (2013). Historical antecedents and local governance in the process of public policies building for coastal zone of Brazil. Ocean Coast. Manage. 76, 30-37. doi: 10.1016/j.ocecoaman.2013.02.011

Martínez, M. L., Intralawan, A., Vasquez, G., Pérez-Maqueo, O., Sutton, P., and Landgrave, R. (2007). The coasts of our world: ecological, economic and social importance. Ecol. Econ. 63, 254-272. doi: 10.1016/j.ecolecon.2006. 10.022

Menezes, G. A., De Andrade, C. D., Rehder, T., Tofoli, C., and Chiaravalloti, R. M. (2014). Gestores Empreendedores: Inovação na Gestão de Unidades de Conservação. Brasília: ICMBio, IPÊ.

Merrie, A., and Olsson, P. (2014). An innovation and agency perspective on the emergence and spread of Marine Spatial Planning. Mar. Policy 44, 366-374. doi: 10.1016/j.marpol.2013.10.006

Ministério do Meio Ambiente (MMA) (2013). Cadastro Nacional de Unidades de Conservação. Available online at: http://www.mma.gov.br/areas-protegidas/ cadastro-nacional-de-ucs

Ministério do Meio Ambiente (MMA) (2010). Panorama da Conservação dos Ecossistemas Costeiros e Marinhos no Brasil. Gerência de Biodiversidade Aquática e Recursos Pesqueiros. Brasília: SBF/GBA.

Muller, M. N., Gerhardinger, L. C., de Lamboy, C., and Ummus, R. (2014). A Call for a Continued Future Ocean Dialogue - From Science to Society. Workshop white-paper, Oceanographic Institute - University of São Paulo.

Newig, J., Günther, D., and Pahl-Wostl, C. (2010). Synapses in the network: learning in governance networks in the context of environmental management. Ecol. Soc. 15:24. doi: 10.5751/ES-03713-150424

O'Brien, K. (2011). Global environmental change II: from adaptation to deliberate transformation. Progr. Hum. Geograp. 36, 667-676. doi: 10.1177/ 0309132511425767

O'Leary, B. C., Winther-Janson, M., Bainbridge, J. M., Aitken, J., Hawkins, J. P., and Roberts, C. M. (2016). Effective coverage targets for ocean protection. Conserv. Lett. 9, 398-404. doi: 10.1111/conl.12247

Oliveira Júnior, J. G. C., Ladle, R. J., Correia, R., and Batista, V. S. (2016). Measuring what matters - Identifying indicators of success for Brazilian marine protected areas. Mar. Policy 74, 91-98. doi: 10.1016/j.marpol.2016. 09.018

Olsen, E., Fluharty, D., Hoel, A. H., Hostens, K., Maes, F., and Pecceu, E. (2014). Integration at the round table: marine spatial planning in multistakeholder settings. PLOS ONE 9:e109964. doi: 10.1371/journal.pone.01 09964

Olsson, P., Folke, C., and Berkes, F. (2004a). Adaptive comanagement for building resilience in social-ecological systems. Environ. Manage. 34, 75-90. doi: 10.1007/s00267-003-0101-7

Olsson, P., Folke, C., and Hahn, T. (2004b). Social-ecological transformation for ecosystem management: the development of adaptive comanagement of a wetland landscape in southern Sweden. Ecol. Soc. 9:2. doi: 10.5751/ES-00683-090402

Ombudsperson of the Sea (2013). Programmatic Agenda for Coastal-Marine Networks. Available online at: http://ouvidoriadomar.tumblr.com

Ouvidoria do Mar (2012). Compreender a Crise para Formular Agendas Proativase Integradas Entre Redes Marinhas-Costeiras. Relatório-Base de Atividade AutoGestionada Realizada na Cúpula dos Povos (18 de junho de 2012). Rio de Janeiro.

Ouvidoria do Mar (2013). Agenda Programática para redes Costeiras e Marinhas. Available online at: http://ouvidoriadomar-blog.tumblr.com

Ouvidoria do Mar (2016). 1o Autodiagnóstico das Redes Costeiras e Marinhas do Brasil: Nós e Redes pela Saúde do Oceano. Rio de Janeiro.
Patterson, J., Schulz, K., Vervoort, J., van der Hel, S., Widerberg, O., Adler, C., et al. (2017). Exploring the governance and politics of transformations towards sustainability. Environ. Innov. Soc. Transitions 24, 1-16. doi: 10.1016/j.eist.2016.09.001

Pinheiro, H. T., Di Dario, F., Gerhardinger, L. C., de Melo, M. R. S., De Moura, R. L., Reis, R. E., et al. (2015). Brazilian aquatic biodiversity in peril. Science 350, 1043-1044. doi: 10.1126/science.350.6264.1043-a

Polette, M., and Vieira, P. F. (2009). The strides and gaps in Brazilian integrated coastal zone management: an undercover evaluation of the scientific community's perceptions and actions. Ocean Yearb. 23, 670-685. doi: 10.1163/22116001-90000203

Pomeroy, R., Mascia, M., and Pollnac, R. (2007). "Marine protected areas, the social dimension," in FAO Expert Workshop on Marine Protected Areas and Fisheries Management: Review of Issues and Considerations (FAO, Rome), 149-275, 330.

Rockström, J., Steffen, W., Noone, K., Persson, A., Chapin, S. F., Lambin, E. F., et al. (2009). A safe operating space for humanity. Nature 461, 472-475. doi: $10.1038 / 461472$ a

Rogers, A. D., and Laffoley, D. A. (2011). International Earth System Expert Workshop on Ocean Stresses and Impacts: Summary report. Oxford: IPSO.

Serafini, T. Z., Medeiros, R. P., and Andriguetto-Filho, J. M. (2017). Conditions for successful local resource management: lessons from a Brazilian small-scale trawling fishery. Reg. Environ. Change 17, 201-212. doi: 10.1007/s10113-016-0990-7

Spalding, M. D., Meliane, I., Bennett, N. J., Dearden, P., Patil, P. G., and Brumbaugh, R. D. (2016). Building towards the marine conservation end-game: consolidating the role of MPAs in a future ocean. Aquat. Conserv. Mar. Freshw. Ecosyst. 26, 185-199. doi: 10.1002/aqc.2686

Steffen, W., Broadgate, W., Deutsch, L., Gaffney, and, O., and Ludwig, C. (2015). The trajectory of the anthropocene : the great acceleration. Anthrop. Rev. 2, 81-98. doi: 10.1177/2053019614564785

Tofoli, C. F., Ribeiro, K. T., Melo, M., and Chiaravalloti, R. M. (2015). Editorial: Iniciativas de Inovação na Gestão de Unidades de Conservação. Biodiv. Bras. 1, 1-3. Available online at: http://www.icmbio.gov.br/revistaeletronica/index. php/BioBR/article/view/582

Toonen, H. M., and van Tatenhove, J. P. M. (2013). Marine scaping: the structuring of marine practices. Ocean Coast. Manage. 75, 43-52. doi: 10.1016/j.ocecoaman.2013.01.001

Trimble, M., Araujo, L. G., and Seixas, C. S. (2014). One party does not tango! Fishers' non-participation as a barrier to co-management in Paraty, Brazil. Ocean. Coast. Manage. 92, 9-18. doi: 10.1016/j.ocecoaman.2014.02.004

United Nations (2012). The Future We Want. Rio de Janeiro. Available online at: https://rio20.un.org/sites/rio20.un.org/files/a-conf.2161-1_english. pdf.pdf (Accessed 25th March 2014).

United Nation's Food and Agriculture Organization (FAO) (2014). Voluntary Guidelines for Securing Sustainable Small-Scale Fisheries in the Context of Food Security and Poverty Eradication. Rome.

van der Hel, S. (2016). New science for global sustainability? The institutionalisation of knowledge co-production in Future Earth. Environ. Sci. Pol. 61, 165-175. doi: 10.1016/j.envsci.2016.03.012

Visbeck, M., Kronfeld-Goharani, U., Neumann, B., Rickels, W., Schmidt, J., Van Doorn, E., et al. (2014). A sustainable development goal for the ocean and coasts: global ocean challenges benefit from regional initiatives supporting globally coordinated solutions. Mar. Pol. 49, 87-89. doi: 10.1016/j.marpol.2014.02.010

Vivacqua, M., Santos, C., and Vieira, P. F. (2009). Governança territorial em zonas costeiras protegidas: uma avaliação exploratória da experiência catarinense. Desenvolv. Meio Ambient. 19, 159-171. doi: 10.5380/dma.v19i0.13759

Wenger, E. C., and Snyder, W. M. (2000). Communities of practice: the organizational frontier. Harv. Busin. Rev. 78, 139-145.

Westley, F., Olsson, P., Folke, C., Homer-Dixon, T., Vredenburg, H., Loorbach, D., et al. (2011). Tipping toward sustainability: emerging pathways of transformation. AMBIO 40, 762-780. doi: 10.1007/s13280-0110186-9

Westley, F. R., Tjornbo, O., Schultz, L., Olsson, P., Folke, C., Crona, B., et al. (2013). A theory of transformative agency in linked social-ecological systems. Ecol. Soc. 18:27. doi: 10.5751/ES-05072-180327

Wever, L., Glaser, M., Gorris, P., and Ferrol-Schulte, D. (2012). Decentralization and participation in integrated coastal management: 
policy lessons from Brazil and Indonesia. Ocean Coast. Manage. 66, 63-72. doi: 10.1016/j.ocecoaman.2012.05.001

World Bank (2006). Scaling Up Marine Management: the Role of Marine Protected Areas. Washington, DC: World Bank report \# 36635-GLB.

Young, O. R. (2010). Institutional dynamics: resilience, vulnerability and adaptation in environmental and resource regimes. Glob. Environ. Change 20, 378-385. doi: 10.1016/j.gloenvcha.2009. 10.001

Young, O. R., Osherenko, G., Ekstrom, J., Crowder, L. B., Ogden, J., Wilson, J. A., et al. (2007). Solving the crisis in ocean governance: place-based management of marine ecosystems. Environ. Sci. and Pol. Sustain. Dev. 49, 20-32. doi: 10.3200/ENVT.49.4.20-33

Zondervan, R., Gerhardinger, L. C., Noronha, I. T., Spalding, M., and Young, O. (2013). Ocean Governance in the Anthropocene. Global Change
24-27. Available online at: http://www.igbp.net/news/features/features/ oceangovernanceintheanthropocene.5.64c294101429ba9184d483.html

Conflict of Interest Statement: The authors declare that the research was conducted in the absence of any commercial or financial relationships that could be construed as a potential conflict of interest.

Copyright $\odot 2018$ Gerhardinger, Gorris, Gonçalves, Herbst, Vila-Nova, De Carvalho, Glaser, Zondervan and Glavovic. This is an open-access article distributed under the terms of the Creative Commons Attribution License (CC BY). The use, distribution or reproduction in other forums is permitted, provided the original author(s) and the copyright owner are credited and that the original publication in this journal is cited, in accordance with accepted academic practice. No use, distribution or reproduction is permitted which does not comply with these terms. 